\title{
Paweł Bachmat
}

\section{Propozycja nowelizacji art. 133 Kodeksu karnego ${ }^{1}$}

The draft amendment of Article 133 of the Criminal Code: The draft amendment, which is the subject of the reviewed petition, contains an introduction to the indicated provision of the Criminal Code of a new type of a punishable act - the use of terms: Polish death camps, Polish concentration camps, Polish Holocaust, polnische Vernichtungslager, polniche Häuser des Todes and other terms contrary to facts. The author of the opinion claims that the petition cannot be considered justified due to juridical and systemic reasons, as it concerns the matter which is currently already legally regulated. Moreover, cases of falsifying history to the detriment of the State or the Polish Nation, which take place outside of the borders of the Republic of Poland, will remain beyond the sphere of the amendment's normative influence because of the condition of a dual criminalisation (in Poland and abroad) according to Article 111 para. 1 of the Criminal Code.

Keywords: Institute of National Remembrance, Criminal Code, petition

Słowa kluczowe: Instytut Pamięci Narodowej, Kodeks karny, petycja

Ekspert ds. legislacji BAS • pawel.bachmat@sejm.gov.pl •

https://orcid.org/0000-0003-3511-5425

\section{Treść i cel petycji}

Przedmiotem petycji jest żądanie podjęcia inicjatywy ustawodawczej dotyczącej nowelizacji art. 133 ustawy z 6 czerwca 1997 r. - Kodeks karny (t.j. Dz.U. 2016, poz. 1137, ze zm.; dalej: k.k. lub Kodeks karny), ulokowanego w rozdziale XVII Kodeksu karnego „Przestępstwa przeciwko Rzeczpospolitej”. W ujęciu zaproponowanym przez autora petycji zmieniany przepis miałby uzyskać następującą postać redakcyjną:

Art. 133 \$ 1. Kto publicznie znieważa Naród lub Rzeczpospolita Polska, podlega karze pozbawienia wolności do lat 3.

$\$$ 2. Kto, dla określenia niemieckich, nazistowskich obozów zagłady, znajdujacych się w granicach okupowanej od 1939 roku przez Niemców Polski, używa

1 Opinia w sprawie nowelizacji art. 133 Kodeksu karnego sporządzona 4 czerwca 2018 r. na zlecenie przewodniczącego Komisji do Spraw Petycji; BAS-WAP 607/18. 
określeń: polskie obozy śmierci, polskie obozy koncentracyjne, Polish death camps, Polish concentration camps, Polish Holocaust, polnische Vernichtungslager, polniche Häuser des Todes $i$ innych niezgodnych $z$ faktami określeń, podlega karze pozbawienia wolności do lat 5.

Biorąc pod uwagę obecne brzmienie art. 133 k.k.: Kto publicznie znieważa Naród lub Rzeczpospolitą Polską, podlega karze pozbawienia wolności do lat 3, należy zwrócić uwagę, że propozycja nowelizacji będąca przedmiotem opiniowanej petycji polega w istocie na wprowadzeniu do Kodeksu karnego, w jednostce redakcyjnej oznaczonej jako art. 133, nowego typu czynu zabronionego o znamionach określonych w $\$ 2$. Przedmiot żądania ujętego w petycji nie obejmuje natomiast zmiany ustawowego opisu typu czynu zabronionego określonego obecnie w art. 133 k.k., lecz jedynie zmienia w odniesieniu do tego typu oznaczenie redakcyjne, jako "art. $133 \$ 1$ ”, co jest bezpośrednią konsekwencją wprowadzenia do art. 133 jednostki redakcyjnej oznaczonej jako „\$2”.

\section{Czy petycja mieści się w zakresie zadań i kompetencji adresata petycji (art. 2 ust. 3 ustawy o petycjach)?}

Petycja dotyczy zmiany ustawy przez Sejm. Zgodnie z art. 95 ust. 1 Konstytucji RP władzę ustawodawczą w Rzeczypospolitej Polskiej sprawują Sejm i Senat. Natomiast stosownie do art. 118 ust. 1 Konstytucji inicjatywa ustawodawcza przysługuje m.in. posłom. Artykuł 32 ust. 2 regulaminu Sejmu, w związku z art. 112 Konstytucji, precyzuje, że poselskie projekty ustaw mogą być wnoszone przez komisje sejmowe lub grupę co najmniej 15 posłów podpisujących projekt.

Uwzględniając powyższe, należy uznać, że petycja mieści się w zakresie zadań i kompetencji Sejmu.

\section{Wymogi formalne (art. 4 ust. 1 i 2 oraz ustawy o petycjach)}

Złożona petycja spełnia wymogi formalne określone w art. 4 ust. 1 i 2 ustawy z 11 lipca 2014 r. o petycjach (Dz.U. poz. 1195, ze zm.) - zawiera oznaczenie podmiotu wnoszącego petycję, wskazuje jego miejsce zamieszkania, adresata petycji oraz jej przedmiot.

\section{Kwestie uznane za istotne w związku z petycją}

Od strony merytorycznej przedstawione w petycji żądanie ogranicza się do wprowadzenia do Kodeksu karnego nowego typu czynu zabronionego do jednostki redakcyjnej oznaczonej jako art. $133 \$ 2$ w następującym brzmieniu: Kto, 
dla określenia niemieckich, nazistowskich obozów zagłady, znajdujących się w granicach okupowanej od 1939 roku przez Niemców Polski, używa określeń: polskie obozy śmierci, polskie obozy koncentracyjne, Polish death camps, Polish concentration camps, POlsih Holocaust, polnische Vernichtungslager, polniche Häuser des Todes i innych niezgodnych z faktami określeń, podlega karze pozbawienia wolności do lat 5.

Problem, na który zwraca uwagę autor petycji w jej uzasadnieniu, jest bez wątpienia doniosły i wymaga roztropnego rozwiązania. Budzą oczywisty sprzeciw przypadki, w których obce media używają fałszujących rzeczywistość historyczną określeń, przy wykorzystaniu których przypisują odpowiedzialność za założenie i funkcjonowanie niemieckich obozów koncentracyjnych na terenie okupowanej przez Niemców Polski narodowi polskiemu lub państwu polskiemu. Tym samym od strony aksjologicznej propozycja uregulowania systemowej reakcji państwa polskiego na tego typu przypadki fałszu historycznego nie jest kontrowersyjna.

Przedmiotowa petycja nie może jednak zostać uznana za zasadną ze względów jurydyczno-systemowych, o czym poniżej.

Po pierwsze, przedstawiona propozycja nowelizacji art. 133 Kodeksu karnego poprzez wprowadzenie nowego typu czynu zabronionego do $\$ 2$ tego artykułu abstrahuje od relewancji systemowej wewnątrz gałęzi prawa karnego. Należy w tym miejscu zwrócić uwagę, że w obecnym stanie prawnym obowiązuje przepis art. 55a ustawy z 18 grudnia 1998 r. o Instytucie Pamięci Narodowej - Komisji Ścigania Zbrodni przeciwko Narodowi Polskiemu (t.j. Dz.U. 2016, poz. 1575, ze zm.; dalej: ustawa o IPN), który wszedł w życie z dniem 1 marca 2018 r. ${ }^{2}$, w brzmieniu: Art. 55a ust. 1. Kto publicznie i wbrew faktom przypisuje Narodowi Polskiemu lub Państwu Polskiemu odpowiedzialność lub współodpowiedzialność za popetnione przez III Rzeszę Niemiecka zbrodnie nazistowskie określone w art. 6 Karty Międzynarodowego Trybunału Wojskowego załaczonej do Porozumienia międzynarodowego $w$ przedmiocie ścigania i karania głównych przestępców wojennych Osi Europejskiej, podpisanego w Londynie dnia 8 sierpnia 1945 r. (Dz.U. z 1947 r. poz. 367), lub za inne przestępstwa stanowiace zbrodnie przeciwko pokojowi, ludzkości lub zbrodnie wojenne lub w inny sposób rażąco pomniejsza odpowiedzialność rzeczywistych sprawców tych zbrodni, podlega grzywnie lub karze pozbawienia wolności do lat 3. Wyrok jest podawany do publicznej wiadomości.

2. Jeżeli sprawca czynu określonego w ust. 1 działa nieumyślnie, podlega grzywnie lub karze ograniczenia wolności.

3. Nie popetnia przestępstwa sprawca czynu zabronionego określonego w ust. 1 i 2, jeżeli dopuścił się tego czynu w ramach działalności artystycznej lub naukowej.

2 Art. 55a został dodany przez art. 1 pkt 6 ustawy z 26 stycznia 2018 r. o zmianie ustawy o Instytucie Pamięci Narodowej (...) i innych ustaw (Dz.U. poz. 369) zmieniającej ustawę IPN z dniem 1 marca 2018 r. 
Powołane uregulowanie art. 55a ustawy o IPN zostało zaskarżone do Trybunału Konstytucyjnego na wniosek Prezydenta RP w trybie kontroli następczej co do jego zgodności z art. 2 oraz art. 42 ust. 1 w związku z art. 31 ust. 3 oraz art. 54 ust. $1 \mathrm{w}$ związku z art. 31 ust. 3 Konstytucji RP. Na dzień sporządzenia opinii sprawa jest zawisła przed TK (sygn. akt K 1 /18), nie został jednak wyznaczony termin rozprawy. Dla dalszego wywodu należy zatem przyjąć, że przepis art. 55a ust. 1-3 ustawy o IPN jest obowiązującym elementem składowym polskiego porządku prawnego.

Korzystając z powyższej przesłanki, należy podnieść, że typ czynu zabronionego określonego w art. 55a ust. 1 ustawy o IPN - z uwagi na dobór znamion składających się na jego ustawowy opis - skonstruowany jest na tyle szeroko, iż zasadniczo obejmuje swoim zakresem stany faktyczne objęte dyspozycją art. $133 \$ 2$ k.k. (w wersji przedłożonej w petycji). W szczególności trzeba zwrócić uwagę, że: [...] publiczne i wbrew faktom przypisywanie Narodowi Polskiemu lub Państwu Polskiemu odpowiedzialności lub współodpowiedzialności za popełnione przez III Rzeszę Niemiecka zbrodnie nazistowskie określone w art. 6 Karty Międzynarodowego Trybunału Wojskowego załączonej do Porozumienia międzynarodowego $w$ przedmiocie ścigania $i$ karania głównych przestępców wojennych Osi Europejskiej, podpisanego w Londynie dnia 8 sierpnia 1945 r. (Dz.U. z 1947 r. poz. 367) może obejmować przypadki, w których wymienione zbrodnie są relatywizowane do miejsca ich popełnienia tj. obozu koncentracyjnego. Zgodnie z art. VI Karty Międzynarodowego Trybunału Wojskowego, do którego odsyła art. 55a ust. 1 ustawy o IPN, w podpunkcie c Karty MTW mowa jest o dopuszczaniu się „zbrodni przeciw ludzkości” rozumianych według tego traktatu jako: morderstwa, wytępianie, obracanie ludzi w niewolników, deportacja i inne czyny nieludzkie, których dopuszczono się przeciwko jakiejkolwiek ludności cywilnej, przed wojną lub podczas niej, albo prześladowania ze względów politycznych, rasowych lub religijnych przy popełnianiu jakiejkolwiek zbrodni wchodzącej w zakres kompetencji Trybunału lub w związku z nią, niezależnie od tego, czy było to zgodne, czy też stało w sprzeczności z prawem kraju, w którym zbrodni dokonano. Ujęcie dyspozycji przyjęte w art. VI ppkt c MTS jest zakreślone szeroko, dotyczy bowiem samego popełnienia zbrodni morderstwa, wytępiania, obracania ludzi w niewolników, deportacji i innych czynów nieludzkich, niezależnie od tego gdzie, w jakim miejscu lub na terenie jakiej jednostki organizacyjnej (obozu koncentracyjnego) zbrodnie te miały miejsce.

Do podobnego wniosku prowadzi próba zdekodowania kolejnego fragmentu przepisu art. 55a ust. 1 ustawy o IPN, w którym ustawodawca odesłał do przypisywania odpowiedzialności: (...) za inne przestępstwa stanowiące zbrodnie przeciwko pokojowi, ludzkości lub zbrodnie wojenne. Pojęcie „zbrodni przeciwko ludzkości” znajduje swoje normatywne odzwierciedlenie w definicji zawartej w art. 3 ustawy o IPN, w myśl której: [z]brodniami przeciwko ludzkości sa w szczególności zbrodnie ludobójstwa $w$ rozumieniu Konwencji w sprawie zapobiegania i karania 
zbrodni ludobójstwa, przyjętej w dniu 9 grudnia 1948 r. (Dz.U. z 1952 r. poz. 9, 10 i 213 oraz z 1998 r. poz. 177), a także inne poważne prześladowania z powodu przynależności osób prześladowanych do określonej grupy narodowościowej, politycznej, społecznej, rasowej lub religijnej, jeżeli były dokonywane przez funkcjonariuszy publicznych albo przez nich inspirowane lub tolerowane. Według art. II powołanej wyżej konwencji w sprawie zapobiegania i karania zbrodni ludobójstwa: ludobójstwem jest którykolwiek z następujących czynów, dokonany w zamiarze zniszczenia w całości lub części grup narodowych, etnicznych, rasowych lub religijnych, jako takich:

a) zabójstwo członków grupy,

b) spowodowanie poważnego uszkodzenia ciała lub rozstroju zdrowia psychicznego członków grupy,

c) rozmyślne stworzenie dla członków grupy warunków życia, obliczonych na spowodowanie ich calkowitego lub częściowego zniszczenia fizycznego,

d) stosowanie środków, które mają na celu wstrzymanie urodzin w obrębie grupy,

e) przymusowe przekazywanie dzieci członków grupy do innej grupy.

Podobnie zatem jak to ma miejsce w przypadku odesłania do art. VI ppkt c MTS, tak i w związku z odesłaniem do art. II konwencji w sprawie zapobiegania i karania zbrodni ludobójstwa, karalne na gruncie art. 55a ust. 1 ustawy o IPN będzie przypisywanie państwu i narodowi polskiemu odpowiedzialności lub współodpowiedzialności za te zbrodnie, „popełnione przez III Rzeszę Niemiecką” jako „zbrodnie nazistowskie” niezależnie od miejsca ich popełnienia, co obejmuje także tereny obozów koncentracyjnych.

A zatem, w przedstawionym stanie prawnym propozycja wprowadzenia nowego typu czynu zabronionego do art. $133 \$ 2$ k.k. jawi się jako nieuzasadniona, gdyż dotyczy materii normatywnej obecnie uregulowanej w obowiązujących przepisach, z tym że wysłowionej w sposób ogólniejszy w ustawowym opisie typu czynu zabronionego $\mathrm{z}$ art. 55a ust. 1 ustawy o IPN. W treści petycji nie uwzględniono ewentualnej propozycji uchylenia przepisu art. 55a ust. 1 ustawy o IPN, co, przy założeniu wejścia w życie art. $133 \$ 2 \mathrm{k} . \mathrm{k}$. w ujęciu zawartym w przedmiotowej petycji, doprowadziłoby do zaistnienia skutku w postaci dublowania regulacji normatywnej. Byłoby to nie do przyjęcia z perspektywy jurydycznego aksjomatu racjonalności ustawodawcy. Poza tym, jak się wydaje, sytuacja, w której dwa przepisy art. 55a ust. 1 ustawy o IPN i art. $133 \$ 2$ k.k. regulowałyby ten sam fragment rzeczywistości, byłaby w praktyce organów wymiaru sprawiedliwości rozwiązywana jako przypadek zbiegu pomijalnego, w którym przepis ogólniejszy (art. 55 ust. 1 ustawy o IPN) konsumowałby przepis zawierający się w nim (art. $133 \$ 2$ k.k.). Oznaczałoby to, że art. $133 \$ 2$ k.k. byłby pomijany w procesie kwalifikacji prawnej czynu.

Po drugie, należy zastrzec, że sformułowany wyżej argument znajduje swoje odniesienie do czynów polegających na fałszowaniu prawdy historycznej w obiegu publicznym, tak jak ujmuje to dyspozycja art. 55 ust. 1 ustawy o IPN: Kto 
publicznie i wbrew faktom przypisuje Narodowi Polskiemu lub Państwu Polskiemu odpowiedzialność lub współodpowiedzialność za popetnione przez III Rzeszę Niemiecka zbrodnie nazistowskie... Przepis art. $133 \$ 2 \mathrm{w}$ brzmieniu zaproponowanym w opiniowanej petycji nie dopełnia znamienia czynności czasownikowej „używa" znamieniem modalnym, wskazującym na publiczny lub jakikolwiek inny (prywatny) charakter działania sprawcy. Oznacza to, że na podstawie opiniowanego uregulowania możliwe byłoby ściganie czynów polegających na używaniu, zarówno w obiegu publicznym, jak i w relacji prywatnej, dla określenia niemieckich nazistowskich obozów zagłady, wskazanych w tym przepisie określeń. Ten kierunek kształtowania zakresu kryminalizacji projektowanego przepisu art. 133 $\$ 2$ k.k. wydaje się chybiony, chociażby z uwagi na trudności w udowodnieniu zachowań podejmowanych $\mathrm{w}$ sferze prywatnej.

Po trzecie, sposób ujęcia niektórych znamion składających się na ustawowy opis typu czynu zabronionego $\mathrm{z}$ art. $133 \$ 2 \mathrm{k}$.k. budzi zasadnicze zastrzeżenia na gruncie precyzji ich wysłowienia. Nie jest właściwe np. użycie skrótu myślowego „niemieckie, nazistowskie obozy zagłady, znajdujące się w granicach okupowanej od 1939 roku przez Niemców Polski”. Znamię czasowe relacjonujące początek funkcjonowania niemieckich obozów zagłady na terytorium okupowanej Polski wydaje się zbędne w świetle powszechnie dostępnej wiedzy historycznej na temat II wojny światowej. Jego ujęcie, poprzez ogólne odwołanie się do roku 1939, nie jest prawdziwe w odniesieniu do fragmentu roku 1939 poprzedzającego atak III Rzeszy na Polskę, a będąc bardziej precyzyjnym, poprzedzającego dzień otwarcia przez Niemców na ziemiach okupowanej Polski pierwszego obozu zagłady. W świetle przedstawionych wątpliwości wydaje się, że rozwiązanie przyjęte $\mathrm{w}$ art. 55a ust. 1 ustawy o IPN, w którym mowa jest o „popełnionych przez III Rzeszę Niemiecką zbrodniach nazistowskich", bez wprowadzenia do ustawowego opisu typu czynu zabronionego znamienia wskazującego na konkretną datę, jest $\mathrm{z}$ technicznolegislacyjnego punktu widzenia bardziej adekwatne. Ponadto należy zwrócić uwagę na niezręczność językową zaistniałą w treści przedłożonej propozycji, zgodnie z którą dla opisania zachowania sprawcy wykorzystuje się następujące zestawienie znamion „Kto, dla określenia..., używa określeń...”. Należy wreszcie zwrócić uwagę, iż przedstawione w art. $133 \$ 2$ dopełnienie zawartej w nim egzemplifikacji w brzmieniu „używa określeń: polskie obozy śmierci, polskie obozy koncentracyjne, Polish death camps, Polish concentration camps, Polish Holocaust, polnische Vernichtungslager, polniche Häuser des Todes” poprzez użycie spójnika koniunkcji „i” („, i innych niezgodnych z faktami określeń”), zamiast spójnika alternatywy nierozłącznej „lub”, prowadzi do skutku, w którym do odpowiedzialności karnej na podstawie art. $133 \$ 2$ k.k. będzie mogła być pociągnięta osoba, która w swoim przekazie użyje wszystkich tych określeń łącznie. Przy takim zdekodowaniu normy wynikającej z brzmienia przepisu art. $133 \$ 2$ k.k., przepis ten, po jego ewentualnym wejściu w życie, pozostałby zatem martwy. 
Po czwarte, należy wskazać, że zaproponowany w art. $133 \$ 2$ k.k. przedział sankcji grożącej za popełnienia czynu zabronionego realizującego znamiona określone w tym przepisie jest niespójny z systematyką Kodeksu karnego. W petycji proponuje się, aby sprawca przestępstwa $\mathrm{z}$ art. $133 \$ 2 \mathrm{k} . \mathrm{k}$. podlegał karze pozbawienia wolności do lat 5. Na tym tle należy zwrócić uwagę, że w obowiązującym na gruncie Kodeksu karnego modelu gradacji wysokości sankcji pozbawienia wolności po „karze pozbawienia wolności do lat 3” (w praktyce chodzi tu o przedział od 1 miesiąca do lat 3 - zob. art. 37 k.k.) następuje „kara pozbawienia wolności od 3 miesięcy do lat 5", a nie od 1 miesiąca do lat 5, do czego prowadziłaby propozycja zgłoszona w opiniowanej petycji.

Po piąte, należy zwrócić uwagę na bardzo ograniczoną przydatność proponowanego typu czynu zabronionego z art. $133 \$ 2$ k.k. do ścigania cudzoziemców dopuszczających się użycia niezgodnych z faktami określeń na opisanie niemieckich, nazistowskich obozów zagłady. W zasadzie będą oni mogli być pociągnięci do odpowiedzialności jedynie za zachowania popełnione na terytorium Rzeczpospolitej, a nie taka, jak się wydaje, była intencja autora petycji. Przypadki fałszowania historii na szkodę państwa lub narodu polskiego, do których dojdzie poza granicami Rzeczypospolitej, pozostaną poza sferą normatywnego oddziaływania projektowanego art. $133 \$ 2$ k.k., co wynika z zasad ogólnych Kodeksu karnego dotyczących odpowiedzialności za przestępstwa popełnione za granicą (rozdział XIII). Należy w tym miejscu przywołać art. $111 \$ 1$ k.k., zgodnie z którym warunkiem odpowiedzialności za czyn popełniony za granicą jest uznanie takiego czynu za przestępstwo również przez ustawę obowiązującą w miejscu jego popełnienia. Prawdopodobieństwo realizacji hipotezy określonej w art. 111 $\$ 1$ k.k., tj. zaistnienie w obcym porządku prawnym tożsamej kryminalizacji jak ta określona w art. $133 \$ 2$ k.k., wydaje się zerowe.

Niezależnie od powyższego stwierdzenia należy dodać, że na gruncie stanów faktycznych opisanych w projektowanym art. $133 \$ 2$ k.k. nie będą mogły zmaterializować się dyspozycje art. 112 i 113 k.k., w których polski ustawodawca przewidział wyjątki od zasady podwójnej kryminalizacji z art. $111 \$ 1$ k.k. W obowiązującym stanie prawnym ani dyspozycja art. 112 k.k., ani art. 113 k.k. nie znajdą bowiem zastosowania $\mathrm{w}$ tych przypadkach.

Zgodnie z art. 112 k.k., niezależnie od przepisów obowiązujących w miejscu popełnienia czynu zabronionego, ustawę karną polską stosuje się do obywatela polskiego oraz cudzoziemca $w$ razie popełnienia:

1) przestępstwa przeciwko bezpieczeństwu wewnętrznemu lub zewnętrznemu Rzeczypospolitej Polskiej,

1a) (utracił moc),

2) przestępstwa przeciwko polskim urzędom lub funkcjonariuszom publicznym oraz przestępstwa wyłudzenia poświadczenia nieprawdy od polskiego funkcjonariusza publicznego lub innej osoby uprawnionej na podstawie prawa polskiego do wystawienia dokumentu, 
3) przestępstwa przeciwko istotnym polskim interesom gospodarczym,

4) przestępstwa fałszywych zeznań, złożenia fałszywego oświadczenia, opinii lub tłumaczenia, posłużenia się dokumentem stwierdzającym tożsamość innej osoby, poświadczającym nieprawdę lub fałszywym - wobec urzędu polskiego,

5) przestępstwa, z którego została osiągnięta, chociażby pośrednio, korzyść majątkowa na terytorium Rzeczypospolitej Polskiej.

Z kolei na podstawie art. 113 k.k. przyjmuje się, że niezależnie od przepisów obowiązujących w miejscu popełnienia przestępstwa, ustawę karną polską stosuje się do obywatela polskiego oraz cudzoziemca, którego nie postanowiono wydać, w razie popełnienia przez niego za granicą przestępstwa, do którego ścigania Rzeczpospolita Polska jest zobowiązana na mocy umowy międzynarodowej, lub przestępstwa określonego w Statucie rzymskim Międzynarodowego Trybunału Karnego, sporządzonym w Rzymie 17 lipca 1998 r. (Dz.U. 2003, poz. 708).

\section{Wnioski}

Przedłożona petycja nie jest zasadna. Choć od strony aksjologicznej propozycja uregulowania systemowej reakcji państwa polskiego na przypadki fałszu historycznego prowadzące do przypisywania wbrew faktom narodowi lub państwu polskiemu odpowiedzialności za zbrodnie niemieckie jest zrozumiała i uzasadniona, to względy jurydyczne nie pozwalają na wprowadzenie do polskiego porządku prawnego przepisu art. $133 \S 2$ k.k. w brzmieniu zaproponowanym w opiniowanej petycji. 